\title{
Language and Communication in the Pentecostal Church of Nigeria: The Calabar Axis
}

\author{
Mercy I. Ugot \\ Centre for General Studies, Cross River University of Technology, Nigeria \\ Offiong Ani Offiong \\ Department of Linguistics and Communication Studies, University of Calabar, Nigeria
}

\begin{abstract}
This paper focuses on language use and communication in the Pentecostal church of Nigeria, with particular reference to Calabar in Cross River State. It is observed that language use and communication arises out of the doctrine characteristics of the church. This shapes all aspects of language and communication use in the church including literary devices in preaching and prayers, neologisms, kinetics and the music of the church. There is no doubt that the influence of the church not just in its beliefs and dogmas but in its use of language and communication has had an effect on the Christian community in Calabar. This effect should be used positively.
\end{abstract}

Index Terms - language, non-verbal communication, neologisms, kinetics, regulators, illustrators and literary devices

\section{INTRODUCTION}

There are many kinds of religion in the world. The oldest is the traditional religion, a religion in which people worship various deities and do homage to them. Others include Buddhism, Judaism, Hinduism, shinatoism etc Isayev(1997) claims that Christianity is five centuries younger than Buddhism having been born in AD 1 with the birth of the author and finisher of the faith, Jesus Christ. Islam followed in the $7^{\text {th }}$ century AD.

One common strand runs through all religions - the adherents, worshippers and devotees have never seen their God but through faith they believe that God does exist (Offiong 2003).

Language therefore becomes the most important means by which Gods faithful can communicate, fellowship or commune with Him and each other. From the libation of the traditional worshippers to the psalms, the Lord's prayer, not to mention all books of the Bible and Koran, words and more words are the medium (Essien 2003).

Many Nigerians, according to Offiong (2003) believe that Pentecostal trends in Nigeria at large and Calabar in particular, take it for granted that the phenomenon emerged in the area for the first time out of the recent increasing contacts of Nigerians with the USA through Bible tracts, video and audios, cassettes, books and personal contacts. This assertion is true to a certain extent because in the past few decades European and American Pentecostal pastors and Evangelists have visited Nigeria for one crusade or another and Nigerian pastors have equally visited Europe and the USA for training in some Pentecostal organizations (Goshit 2002). Consequently in Nigeria, Pentecostalism exhibits traits of American Pentecostal influence in their language techniques and concepts. Its popularity has also been aided by tele-evangelism which started in the USA and gained popularity in Nigeria. Almost all notable tele-evangelists from the USA have had their programmes aired in the local media or been hosted here in Nigeria (Owens-Ibie 2002). The success of this can be attributed to tele-evangelism taking advantage of the total grip that the media have on popular culture (Marshall - Frantini 1998).It can therefore be said that Pentecostalism is alien to Nigeria and Calabar in particular.

Pentecostalism as a religious phenomenon owes its origin to the event of the day of the Pentecost in Acts of the Apostles chapter 2:1-4 Pentecostalism derives its name from the historical event of the Pentecost. Pentecostalism is experiential Christianity resulting in the baptism of the believer in the Holy spirit as shown in speaking in tongues.

Baptism in the Holy Spirit follows conversion and is evidenced by speaking in tongues. The phenomenon of speaking in tongues is referred to as glossalias a Greek word meaning, "tongues" (Offiong 2003) The power of the Holy spirit in the individual is manifested in the gift of the Holy Spirit which Paul lists in 1 Corinthians 12:4-10. Unlike the Aladura and some of the historic churches where infant baptism is encouraged. adult baptism by immersion is an important characteristic in the Pentecostal churches and organizations. (Offiong 2003).

\section{A. Pentecostalism in Calabar}

It is pertinent to point out that the early Pentecostal churches in Calabar emerged between 1933 and 1965. The prevailing socio-political condition during the period did not facilitate the rapid and noticeable impact of Pentecostalism in the area. However, Offiong (2003) points out that contemporary development in Pentecostalism since 1970 has made the phenomenon a force to be reckoned with in Calabar. Although it is part of a global phenomenon whose origin 
cannot be explained in terms of a single cause. However, several factors were responsible for its emergence in Calabar and these include historical, sociological, economic, political and religious factors. From a historical perspective, missionary enterprise in Nigeria in the $19^{\text {th }}$ century was followed by Scottish Presbyterian Mission in Calabar in 1849 (Kalu 1980, Hacket 1988). In the 1970s came the influx of new spiritual activities in Calabar (Shorter 1991).

The emergence of the youth in the hierarchy of the church for leadership ambitions led to an out- pouring of youths from the historic churches to the Pentecostal churches where they could compete favorably for leadership roles. From an economic point of view, the emergence of a new youthful educated elite class who were mostly unemployed or underemployed has encouraged the growth of the church and movement as more people find jobs as "pastors" in Calabar. Many were also attracted to the wealth promised by the Pentecostals. Politically, the establishment of a church grants recognition from government and the society at large. It is also a source of power and control. Spiritual ineffectiveness of the historic churches in dealing with the devil for instance led to the growth of the Pentecostal churches which offered myriad solutions to almost every problem. They offered miracles to their members and promised them wealth (Offiong 2003).

\section{B. Language}

Crystal (2003) views language as a particular variety or level of speech. At its most specific level, it may refer to the concrete act of speaking, writing or signing in a given situations. Ndimele (1999) says language is often described as a semiotic system, because it entails the use of certain agreed-upon symbols or signals to convey meaning from one person to another within a speech community.

Language is essentially a communication system in the sense that it associates meaning i.e the message with a set of signs, sounds or symbols (Ndimele 1999).

Olaoye (2007), citing Sapir (1921p.8) who says "language is a purely human and non-instinctive way of communicating ideas, emotions and desires, by means of voluntarily, produced symbols" Eka and Udofot (1996) view language as the most brilliant of human inventions. It is also about the most useful. By means of language, people who live together are able to interact and express their thoughts and feelings.

Gimson (1980p.4) describes language

As a system of conventional signals used for communication by a whole community. This pattern of conventions covers a system of significant sound units, the inflection and arrangement of words and the association of meaning with words.

Hall (1968p.158) in his essay on language says that language is.

The institutions whereby humans communicate and interact with each other by means of habitually used oral auditory arbitrary symbols.

Again Sapir (1949p.1) postulates that

In the first place, language is primarily a system of phonetic symbols for the expression of communicable thoughts and feelings. In other words the symbols of language are differentiated products of the vocal behaviour which is associated with the larynx of the higher mammals.

Essien (2003) posits thus

Put more simply, language is a system of rules and principles in which sound, structure and meaning are integrated for communication.

Chomsky and Halle (1968) give a definition of language as follows.

We may think of a language as a set of sentences each with an ideal phonetics form and associated intrinsic and semantic interpretation.

Based on all these definitions and views the essential characteristics of language therefore includes its being arbitrary and conventional, its use being perculiar to human beings its being non-instinctive and therefore learned and its function of being the tool with which a speech community exchange ideas and express emotions.

\section{Non Verbal Communication in Preaching}

Although language is communication, for the purpose of this paper we shall also be looking at other aspects of communication, such as non-verbal communication. This includes body movement or kinetics and how different parts of the body are used to aid communication. The pastor uses facial expressions, eye contact, emotional tears, regulators such as head nodding, hand gestures waves his hand to emphasis a point, he shifts in posture, and illustrators such as a wave of the hand, pointing in the direction of an entity etc. touching and so on (Nelson \& Pearson 1990).

The Preacher in the Pentecostal church in Calabar violates all spatial proximity as he may start off with a public distance up at the altar or at the lectern, then move down and around at a social distance to a personal distance where he may stand and pointedly talk to an individual. When he wants to pray for someone he operates at an intimate distance and may lay his hand on the person while praying.

Communication may also involve spatial proximity. Ekpe (1997) points out that this has to do with personal space between the speaker and the listener in a communication exchange. Such exhibitionist behavior is not one-sided as very often, the congregation mimics the same gestures the Pastor makes.

For formal interaction the public distance is the farthest and is used when someone is speaking to an audience. The distance falls between 12 feet to 25 feet. 


\section{THEORETICAL FRAMEWORK}

There are many models of communication but for the purpose of this paper, we shall apply the consumer or gratification model of communication. This theory best suits the Pastor and his congregation where emphasis is placed on WHO is, the communicator at the expense of the more important WHOM- the receiver or audience. Below is a representation of the consumer/gratification model. This model is a refined model of Lasswell's model. Here there is some final feed back as opposed to Lasswell's model which offered no feedback (Ugboajah 1985).

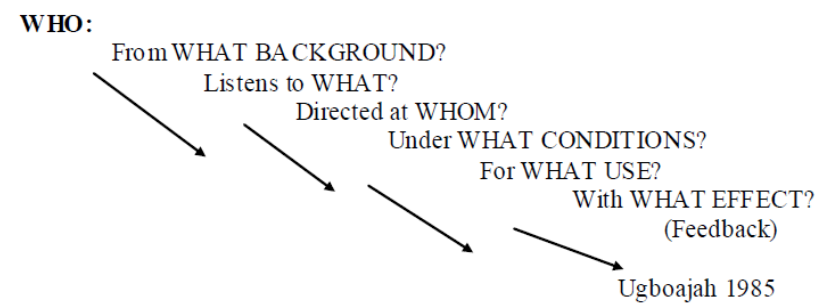

Fig A: The Consumer/Gratification Model.

\section{Language Use and Communication in the Pentecostal Church}

The power of words cannot be over-looked. Words can be vitriolic, inciting, offensive, insolent, provocative, persuasive, destructive, etc (Essien 2003)

In religion we experience the spiritual power of speech. Religion is concerned with many relationships to a supernatural being or power in the great drama of existence. Such a being is referred to as God in as many languages as human beings speak. Thus we have Abasi, Obazi, Chineke, Dieu, Ogun, Allah, Esowo etc. to mention a few.

The dominant language in use in most Nigerian churches is English. It is the official language in Nigeria and serves as the main language of the Pentecostal church of Nigeria. The church use mostly English to preach, to sing and to pray. It is therefore the dominant language of the church as according to Wardhaugh (1986p344) it has "the full panoply of uses that signify a standard language and invests its users with prestige, self-confidence and power which includes economic, educational, academic, intellectual, socio-cultural and political powers".

The manifestation of language use and communication in the Pentecostal churches in Calabar is reflected mostly in preaching, praying and singing of choruses.

\section{LITERARY DEVICES IN PREACHING}

The bible is the sole authority of the Pentecostal churches and organizations. The authority of the preacher and the interpreter of the Bible is also important.

First of all, preaching involves a varied voice for emphasis with the pitch of voice, rising and falling dramatically. Gestures and facial expressions are used effectively for non-verbal communication. The language is often forceful. The audience/congregation is addressed almost personally with a lot of personal devices such as use of the personal pronoun including; we, us, I, you, ourselves etc. Pronouns are used in such a way as to include the preacher.

1. "Let us give a clap offering to the Lord".

A clap offering is also a dramatic action. It helps hold the attention of the congregation. It is dramatic in that even if the preacher said something he felt was worth clapping for, he gives the glory to God. "I welcome all of us to this service...." "us" instead of the conventional "you" shows deliberate inclusion of the speaker and is therefore an inclusive device.

The preacher sometimes preaches interactively. This way, he involves the audience by asking them polar questions that require a clear yes or no answer.

2. "Am I right?"

Sometimes he uses the service of tag question

3. "Our God is a miracle working God, isn't He?

This keeps his audience (the congregation) alert. He may also call for someone in the congregation to read a Bible passage he is going to refer to. He may also suddenly burst into a song that the church sings along with him. He may also make general requests such as

4. "Somebody praise the Lord...."

"Somebody say Amen!"

"Can we give a clap offering unto the Lord."

In his voice production, the Preacher articulates in a loud voice and may sometimes quicken and suddenly slow his preaching for effectiveness. He plays a lot on the effect of shouting suddenly and pausing for dramatic effect. He injects emotion into his voice. Rhetorical questions are used as a device. The preacher does not expect any answer and this may affect the congregation more positively than any direct question or statement.

5. "Are we supposed to sit at home on Sunday, instead of coming to the house of God?" 
The Preacher makes use of hyperbole as a conscious exaggeration either as comic relief or to heighten the effect of his message.

6. "Our God is so big that we are like ants in His presence."

Repetition is an important rhetorical device which reiterates words, phrases or sentences for the sake of emphasis. It can be used to enlighten effect and to re-enforce a speaker's message in oral delivery (Ekpe 1997).

7. "Your liberty is today, today, today! Shout I am free, free, free, free! In the name of Jesus".

8. "Amen, amen and amen".

This also involves repeating after the preacher as would be found in a classroom setting.

9. Preacher; "what did I say?'

Congregations "Give unto God what is His!"

The preacher also makes use of interjection while preaching
10. Pastor -Hello?
Congregation - Hi!
11. Pastor - Amen?

Congregation - Amen!

"Halleluia" too is used as a dramatic pause in preaching or giving testimonies. The Pentecostal movement in Calabar provides for testimonies at church services and worship, tarry nights and altar calls. Testimonies include what good things God has done for members of the church.

12. Preacher/ speaker - Halleluiah!

Congregation - Amen!

Preacher/ speaker - Amen!

Congregation - Halleluiah!

13. Preacher - God is good

Congregation - All the time!

Preacher - And all the time,

Congregation - God is good!

\section{NEOLOGISMS}

The church also introduces new vocabulary into the English language and such new vocabulary is widely accepted. Some of them include,

14. "Send forth" instead of "send off" which is now viewed with suspicion by the church as it is seen as derogatory and damning. The "forth" clearly alludes to the Biblical language as in "go forth and multiply" (Gen 9:7).

15. "Congregants" instead of "congregation"

16. "Sow a seed" - spiritual investment

17. "Fruit of the womb"-pregnancy

18. "It is well" instead of "Fine, thank you" or "Very well, thank you"

Respondents to the question "How are you? How is your family, how is work? and all such questions that Nigerians always ask, often give the reply "it is well" even if the respondent is sick, or going through rough times, as it is not viewed as proper to air your sorrows publicly when God can deal with them.

Other new expressions are seen in prayers

19. "Father in the name of Jesus begin to loose this man, loose, loose, loose.......

"Loose" here implies freeing the person from the hold of the devil.

According to Terry (1999) "binding" and "loosing" were common expression in Jesus' day for forbidding and permitting. Based on Jewish and Hebrew history, what a rabbi forbade he was said to "bind". What he permitted, he was said to "loose".

20. "We come against any enemy...."

To come against" is to deal with opponents or enemies. Standard English would use the expression "to come up against". The preposition "up" is missing.

21. "born again" is to re-dedicate ones life to a new way of living in Christ.

22. "Amen" is now often said as "Amem" in Calabar and in the Efik language "emem" means peace, so one is not sure if this is a corrupt form of that particular word.

The church also uses language to persuade. The language of persuasion is a process by which someone tries, usually by reasoning arguments, logic, appeal to sound judgment, verbal finesse or artistry to win someone to a particular point of view.

23. "The Lord has given you so much, why can't you give this token, as tithe, unto the Lord?"

The language of the Pentecostal church is also reflected in new names given to children. One of the most obvious linguistic means of establishing people's identity is through the giving of names (Ugot 2005 citing Singh and Peccei: 2004). 
Religion uses names in the same way to establish its identity in the individual. This was a common feature in the historic Christian churches, where any English sounding names were considered as Christian names, hence, children were often given names such as Ambrose, Faith, Alphonsus, Theophilus, Peace, Blessing, Comfort, Hope, etc.

The Pentecostals in Calabar discourage native names except if it is clearly linked to God as in UduakAbasi "God'swill". However, even if it is, the preference is that such a name be translated into English. For instance children these days answer names like Praise, a direct translation of an Ibibio/Efik name Itoro. Other names include God'slove, God'sgift or simply Gift, Wisdom, Goodness, Best man, Gladness, Evidence, Countwell, ThankGod, Touch not, Wonders, Treasure, Unity, Kingdom, Divine, Anointing. Such names have a Christian message behind them.

\section{LANGUage Use in Prayers AND ChORUSES}

Language use in the church is also evident in prayers. Prayers are often said loudly, accompanied with vigorous jumping and shaking of the head and hands. Use of commands rather than entreaties are a common usage.

24. "In the name of Jesus come out! I command you to come out in the name of Jesus, out! Out! Out!"

"we call on the Holy Spirit to send down his fire, fire! Fire! Fire!

25. "No arrow that flies by night or day..........!"

"Break the yoke.

"Back to sender........!

"Die by fire! Die by fire!"

It is clear that the church uses a lot of exclamations. This is characterized by high pitched voices and shouting. Such prayers are also said in emotionally - ladden voices.

The Holy Spirit is often associated with fire as expressed in the Pentecost (Acts 2:1-5). The 'yoke' is like a chain. Yule (1985) refers to language as having cultural transmission in that a speaker of a language picks up that language from the community he grows up in and is not born with the knowledge of the language, not even that of his parents. Language therefore is passed on from one generation to the next and humans are born with an inmate predisposition to acquire language. The language of the church therefore is passed on from generation to generation, it has been growing and changing as language is very dynamic. This change is best reflected in the music of the Pentecostals which has generally been caught on by even the historic churches.

Although most Pentecostal churches have discarded the singing of the traditional hymns, some do still sing them but with a faster, livelier beat, not using the traditional organ as used in the historic church but drums, saxophones and the piano.

The choruses are sung mostly in the languages of the community, from Standard English (SE) to Nigerian Pidgin (NP) to the local language of Calabar (Efik). Let us look at two choruses in SE

26. He has given me victory

I will lift Him higher

Jehovah, I will lift Him higher

It is presumed that Jehovah has already been lifted high and can go higher.

27. ... Glory, glory, Lord

We give you glory Lord

Glory, glory, Lord

You are the mighty God...

Songs in NP include

28. ...Jesus power, superpower,

mamiwota power, powerless

power.

Jesus power, superpower,

demonic power, powerless

power

Mamiwota refers to the water spirit, and the devil is alluded to in "demonic power"

29. ... Satan don fall for ground o

Macham, macham

E don fall for ground o

Macham, macham...

Translated, we have Satan has fallen on the ground Step on him, step on him He has fallen on the ground Step on him, step on him...

This song/chorus is often accompanied by stamping of feet. The use of words like "satan, demonic, mamiwota," shows the extent to which Pentecostal churches in Calabar focus on the devil and his activities. This is a distinctive feature of the movement in Calabar. Evil is clearly personalized while promoting the belief and fear of the devil which they claim has the power to subdue.

$\begin{array}{ll}\text { 30. God na helele } & \text { NP } \\ \text { God na waya o } & \text { NP }\end{array}$ 


\begin{tabular}{|c|c|}
\hline God na helele & NP \\
\hline God na waya o & NP \\
\hline Nobody be like am & NP \\
\hline Nobody dey like am & NP \\
\hline Ewo - o, nwannem & - Igbo \\
\hline God na helele. & NP \\
\hline
\end{tabular}

Translated thus

God is excellent

God is wonderful

Nobody is like Him

Nobody is like Him

My brother/sister

God is excellent

Ewoo is a meaningless emotional exclamatory expression in Igbo, that can be used in many situations from the joyful to the sorrowful..... The song is a code mix of NP and Igbo. Nwannem is "my brother" or "my sister", literally "my mother's child". According to Singleton (2000) this sudden change from NP to Igbo is conversational code-switching.

The church is equally influenced by the language of the community. Thus we have choruses sung in Efik (a Lower Cross language spoken in Calabar).

31. "Eyen Abasi, amanam o

Awo inamke mkpo ikanodo

Awo inamke mkpo ikanodo

Awo inamke mkpo ikoanodo

Sosongo.

Translated as follows,

God's child - you have done well

One cannot do more than that (Repeat twice more)

Thank you

"God's child" here refers to Jesus

32. Woiyo! Akanam nkwe

Woiyo! Akanam nkpopke

Woiyo! Akanam nkwe, nkwe, nkwe,

Imami etiede nte ima Abasi

Woiyo! I've never seen

Woiyo! I've never heard

Woiyo! I've never seen, seen, seen, a love like God's love.

Woiyo is just an exclamation used in the same way as the Igbo "ewoo". This was a popular religious song from the genre of Gospel music that became so popular in Calabar and its environs that it worked its way into the church and even into the historic churches. Sometimes, choruses are picked from other language speaking communities.

A song in Ijaw, a language spoken by the major tribe in the creeks of the Niger-Delta

33. Ayiba preye preye ebiye $x 4$

Ayiba nuaee, nua aa $\mathrm{x} 3$

Ayiba preye preye ebiye $x 3$

Translated thus

Whatever God gives is good

Thank you God

Whatever God gives is good.

\section{CONCLUSION}

The Pentecostal church in Calabar is obviously a force to be reckoned with as its influence is felt in everyday use of language and communication. The language of the church is used in not just stimulating action or seeking the compliance of its members but also in all activities of the church such as preaching praying and singing. It is all expressed through the devices of speech and the use of not just English, the official language, but Nigerian pidgin and the language of the community to spread the doctrines of the church. It is hoped that the church would make use of its strong language and communication devices to promote not just a better Calabar but progressive Nigeria.

\section{REFERENCES}

[1] Chomsky, N \& M. Hall. (1968). The sound patterns of English. New York: Harper and Row

[2] Corbett, E. (1977). The Little rhetoric handbook. New York: John Wiley.

[3] Eka, D. \& Udofot, I. (1996). Aspects of spoken language. Calabar: Bon Universal Ltd.

[4] Ekpe, S. I. (Ed) (1997). Aspects of rhetoric. Calabar: Association for Popular Culture. 
[5] Essien, O. (2003). Language and power. An inaugural lecture. University of Calabar, Calabar $17^{\text {th }}$ November, 2003.

[6] Gimson, A. C. (1980). An introduction to the pronunciation of English. London: Edward Arnold.

[7] Goshit, Z. D. (2002). The influence of religion on the reform movements in the $19^{\text {th }}$ century USA: Lessons for Nigerian pp $33-$ 45. In S.O.O. Amali, N. Owens - Ibie, F. Ogunleye, O. Adesina and C. Uji, (Eds) Religion in the United States of America. Ibadan: American Studies Association.

[8] Hackett, R. I. J. (1998). Religion in Calabar: The religious life and history of a Nigerian town. Berlin: Water de Gruyter.

[9] Hall, R. A. (1968). An essay on language. Philadelphia and New York: Chilton Books.

[10] Isayev, M. I. (1977). National languages in the USSR: Problems and solutions. Moscow: Progress Publishers.

[11] Kalu, O. U. (1980). The history of Christianity in West Africa. Essex: London Group.

[12] Marshall - Frantani, R. (1998). Meditating the global and local in Nigerian Pentecostalism. Journal of Religion in Africa. $28: 3$. 278-315

[13] Ndimele, O. (1999). Semantics and the frontiers of communication. Port-Harcourt: University of Port-Harcourt.

[14] Ndimele, O. (2006). Fundamentals of mass communication, Port -Harcourt: M \& J Grand Orbit Comm Ltd.

[15] Nelson, P. E \& Pearson, J. C. (1990). Confidence in public speaking. Dubuque: WMC Brown.

[16] Offiong, E. A (2003). Pentecostalism in Nigeria: Calabar experience. 1970-1995. Calabar: Glad Tidings Press Ltd.

[17] Olaoye, A. A. (2007). Introduction to sociolinguistics. Abuja: Ogunleye Publishing and Printing Press.

[18] Owens - Ibie, N. (2003). Broadcasting religion, narrow casting morality and thoughts on mass media aided fundamentalism in the USA. Pp 205-215 in S.O.O. Amali, N. owens-Ibie, F. Ogunleye, O. Adesina \& C. Uyi (Eds) Religion in the USA. Ibadan: American Studies Association.

[19] Sapir, E. (1921). Language: An introduction. New York Harcourt Brace.

[20] Sapir, E. (1949). Culture, language and personality: Selected essays. California: California University Press.

[21] Shorter, A. (1991). The church in the African city, London:_Geoffrey Chapman.

[22] Singh I. \& Peccei, J. S. (Eds) (2004) . Language, society and power: An introduction. London: Routledge.

[23] Torrey, R. A. (1999). The Bible answer book. New Kensington: Whitaker House.

[24] Singleton, D. (2000). Language and the Lexicon: An Introduction. New York: Oxford University Press.

[25] Ugboajah, F. (1985). International Keynotes magazine 1:1.20

[26] Ugot, M. (2005). Agwagune names: A socio-linguistic appraisal. Calabar Journal of Liberal Studies (CAJOLIS)_86-104. 8:2

[27] Yule, G. (1985).The study of language. Cambridge: Cambridge University Press.

Mercy I. Ugot is currently a Senior Lecturer in the Centre for General Studies, Cross River University of Technology, Calabar, Nigeria. She has a B.A (Hons) in Modern Languages from the University of Wolverhampton, England, 1983, a Post-Graduate Diploma in Education from the University of Calabar, Nigeria 1993 and an M.A and Ph.D in Linguistics (Morphology) 2002 and 2008 respectively also from the University of Calabar, Nigeria.

She has taught French and English in the Cross River State College of Education, Akamkpa and the Polytechnic Calabar, from 1985-2001.

Dr. Ugot is a member of the Linguistic Association of Nigeria, the English Language Association of Nigeria and is a registered member of TESOL.

Offiong Ani Offiong is an Associate Professor in the Department of Linguistics and Communication Studies, University of Calabar, Calabar, Nigeria. He has been the Head of Department (2008-2010) and is presently the Sub-Dean of Faculty of Arts, 2010 date. He holds a B.A. (Hons.) in Linguistics, a Masters and a Ph,D in Sociolinguistics in 1983, 1986, and 2007 respectively. Dr. Offiong is listed in the Linguist list. A member of the Linguistic Association of Nigeria. 